\title{
Implications of Free Trade Area for Poverty, Household Welfare And Economic Development In Nigeria
}

\author{
Idris Abubakar $^{1}$ (D), Thomas Abaukaka ${ }^{2}$ D, Muhammadkabir O. Momoh ${ }^{3}$ (D) \\ ${ }^{1}$ Department of Economics, University of Abuja FCT- Nigeria. \\ ${ }^{2}$ Department of Economics, Federal College of Education, Okene, Kogi State, Nigeria. \\ ${ }^{3}$ General Studies Department, Auchi polytechnic, Auchi, Edo State, Nigeria.
}

\begin{abstract}
Keywords: Free trade area, Income Per Capita,

Poverty, Unemployment, Welfare, World Bank, Nigeria.
\end{abstract}

JEL Classification: F1, F2, F4, F6.

\section{Received Date: \\ 07-03-2020 \\ Accepted Date: \\ 04-09-2021 \\ Publication Date:}

30-09-2021

\section{ABSTRACT}

Purpose of the study: The study aims to investigate the implications of free trade areas for poverty, household welfare and economic development in Nigeria.

Methodology: This study employed a fully modified least squares (FMOLS) regression technique. The income per capita and unemployment out of many macroeconomics indexes were employed in this study to measure welfare and poverty implications of free trade area respectively. To enable the study, determine the policy and decision-making implications of the free trade area on Nigeria economy, historical data were drawn from the central bank statistical bulletin for 27 years.

Main findings: The estimated results revealed that the income per capita (welfare) model demonstrated a fair view of free trade scenarios as indicated by the explanatory variables; export contributions to gross domestic product and foreign direct investment contributed positively to the welfare of the individual. Besides, the study also found foreign direct investment and export contributions to gross domestic product to have a negative relationship with unemployment, which implies a reduction in the unemployment rate in Nigeria.

Research implications: This study documented that households' welfare will be increased by free trade area, while unemployment will also be reduced by participating in free trade area. Based on study findings, policies makers, academia, researchers, the and government will find the study relevant in making policies that promote foreign direct investment, export contributions to the growth of the economy and gross domestic product such as reduction in tariff, simplifying trade regulations, increasing the availability of credit to exporters, creations of duty drawback, improving cooperation among economic actors and overall structural changes which will have positive implications on the households welfare, poverty and economic development.

The novelty of the study: The relevance for free trade area as one among economic policies to promote the welfare and reduce poverty among nations is gaining momentum globally especially African continent. Given the paucity of studies on this area, the study is undertaken as a framework to determine what the implications of free trade areas will be among the African continent.
Copyright: (C) 2021. The Authors. Licensee: IJSSER. This work is licensed under the Creative Commons Attribution License.

Please cite this article as: Abubakar, I., Abaukaka T., \& Momoh, M.O. (2021). Implications of Free Trade Area for Poverty, Household Welfare And Economic Development In Nigeria. International Journal of Social Sciences and Economic Review, 3(3), 111.

doi.org/10.36923/ijsser.v3i 3.88

\section{Read online:}

Scan this QR code with your smart phone or mobile device to read online.

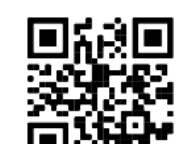

\section{INTRODUCTION}

Eradicating poverty, promoting household's welfare and economic development remained the dominants objectives and major concerns to every government most especially developing nations, in which Nigeria is included. The economies of most countries from the Africa region are characterized by the aforementioned problems. This requires governments of most countries to ceaselessly formulate numerous policies that are capable of re-organising their politics, economics and social institutions for advancing the welfare and economic development (Obomeghie \& Ugbomhe, 2021).

Despite these monumental policies, most African countries poverty indexes still lag behind the global poverty line. The income per capita among individuals in the African countries remains abysmally low which indicate poor living standard and low hygienic condition and consumption of low nutritional foods. The worst scenario is the poor institutional transformations which may mitigate the competitive performances of the various sectors of the economy to participate in international trade creditably (Obomeghie \& Ugbomhe, 2021). Nigeria economy is not exempted from the poor living standard bedevilling the continent as evidence by its recent per capita income of US $\$ 1,809$ and a total output of US $\$ 2,450$ billion central banks of Nigeria $(\mathrm{CBN})(2017)$. Most Nigerians lack basic amenities like a house, hygienic water and adequate consumption of nutritional foods, faced with a precarious health system and accessing health is very cumbersome. Low infrastructural developments such as roads remain dead traps thereby undermining the importance of transportation to the economy. 
The epileptic supply of electricity is another frustration bedeviling the industrial sectors of the economy thereby impacting adversely on the competitiveness of the economy. The fiscal policies in the area of taxation are another limiting factor to the competitiveness of the industrial sectors most especially the small and medium enterprises, which in turn affecting the wellbeing of the economy (Abubakar \& Obansa, 2020). The lending rate of interest remained one of the major constraints to investors which limit the investments undertakings and the entrepreneurial ability. This tends to lead to the active participation of investors in manufacturing activities as one of the indexes that measure the competitive strength of an economy. Eradication of poverty, increase in the welfare of the households and the overall growth of an economy may be difficult for a nation whose domestic economy competitive strength is weak. Of recent, most countries including Africa nations have discovered the need for free trade area which may entail the abolition of all or at least the relaxation of some trade restrictions among member countries as a universal remedy for stimulating hailing economies (Abubakar \& Obansa, 2020; Puzenat et al., 2010). This is with the view to lifting the countries from abject poverty, promoting households' welfare and enlivening overall economic development in the continent.

However, the case of Nigeria differs because, despite the rich natural and human resources the country is blessed with, its trades with other countries with all kinds of restrictions have not shown increasing progress that reflects on the poverty, wellbeing and development of its economy. Therefore, it becomes very urgent to explore what the implications of ratifying the agreement of free trade in the African continent will be on the Nigerian economy given the level of its competitive strength which is put at about 47.0 percent and making it $16^{\text {th }}$ position. This makes it came after the most fifteenth (15th) competitive economies in Africa as indicated in the competitive ranking of 44 African countries economies (Gap, 2017). The low performance index is an indication of the poor feat of the Nigerian market. This casts doubt on the country expectation if involved in free trade area as a pathway to evade abject poverty, increases household's wellbeing and boosting economic development. To measure the impact of trade policy reforms on rural poverty in Nigeria, Omoke and Busari (2008) employed a computable general equilibrium (CGE) model to examine the rural inequality implications of the removal of import duties. Their study revealed that trade liberalization policy led to reduction of real wage and income as well as further deterioration of rural inequality. The relationships between income per capita as the outcome variable which measures the poverty and indexes like foreign direct investment, export contributions to the gross domestic product were not explicitly captured in their model. in another study, Balogun and Dauda (2012) investigated the poverty and employment impact of trade liberalization in Nigeria using econometric analysis to estimate the system equation models and their result documented adverse relationship between disaggregated per capita incomes(industrial and agricultural sectors), total labour force as the dependent variables and trade liberalization represented by terms of trade, exchange rate, foreign reserve, domestic price index, and trade openness among the explanatory variables.

To bridge this gap, this study sets to evaluate the preparedness of Nigeria economy to optimally participate in continental free trade to alleviate poverty, promote the hold welfare and stimulate the development of its economy. The ordinary regression method was employed to permit the determination of the relationship between poverty which is measured by the income per capita of the households and the export contribution to growth, foreign direct investment, and gross domestic product as the determinant's variables.

\section{LITERATURE REVIEW}

Free trade implies have sub-regional, regional, and continental trade agreements whereby goods and services can be exchanged without some underlying restrictions to trade among nations. The proponents Moroney and Walker (1966); Ricardo (1956); and Krugman (1993) of the free-trade doctrine starting from the absolute, comparative advantage to New trade Theory believed that when goods are traded amongst nations it will foster economic growth and prosperity of trading among partners. Though, the underlying aim is to achieve efficiency of resource use and a competitive production base. The efficiency of resource employment is based on the fact that labour abundant countries produce about-intensive goods to exchange for capital intensive goods. In the long run, it is expected that the competition for a superior position in the international market will push developing countries like Nigeria to adopt and developing technology. All these are expected to bring about value additions which are critical for creating linkages in the employment generation, income gains and reduction in poverty prevalence.

The poor can benefit from trade if the prices of commodities they consume are reduced and the prices of what they produced are increased (Bank, 2018). This tends to change relative prices in both product and factor markets. In a nutshell, trade can impact the national economy by reducing the cost of products that are not domestically available at reasonable prices and increase the quality and variety of such economic consumptions in the marketplace. The pursuit of the policy of trade liberalization seems to be related to the pursuit of sustained growth as evidence from some countries experiences in growth accelerations during the time of their trade reforms, such as in Taiwan (1962), Brazil (1967), China (1991), India (1991), and Poland (1991) (Irwin, 2019). The economic recovery and growth plan of Nigeria (ERGN) for three years covering 2017 and 2021 is to turn the economy around to achieve sustainable growth with a focus on the policy of industrialization, export orientation and improved economic competitiveness. This has become necessary owing to the fact that Nigeria and other African continents lays behind in the global market performance due to low industrialization. It is hoped that with a more outward trade orientation, the Nigerian economy will increase its national income, and hence reduced poverty incidence (Ahmad, 2021).

Dismantling of trade restrictions across Africa is believed to be beneficial to Nigerian manufacturing (Ihua, Ike-Muonso, Taiwo, \& Mba-Kalu, 2018). The AITCR report emphasized the need for integration for economic transformation and sustainable socioeconomic development in Africa as it is a development strategy aimed at aggregating Africa's small countries into one large market that can deliver economies of scale, improved competitiveness, foreign investments which could enable poverty reduction in the region. To this end, African leaders and policymakers have been making concerted efforts to have an economic community. This led to the recent agreement in 2017 to establish the African continental free trade area (AfCFTA). 


\subsection{Conceptual Clarifications of Free Trade Area}

The free trade area is the existence of a common trade block between trading partners of sub-regional, regional or across continental blocs where all forms of trade restrictions by the international community are removed and leading to the establishment of customs unions by adopting a common trade restriction within the regional economic community (Grossman \& Krueger, 1995). The sub-regional and regional trade blocks are the precursors for continental integration. Nigeria is a member of the Economic Community of West Africa States with an average applied tariff on imports of 5.60 from the member trading blocs (Ihua et al., 2018). The trade among African countries faces high barriers with average protection of $8.7 \%$ (Mevel \& Karingi, 2012). According to $\mathrm{Ma}$ and Lu (2011), the principle of comparative advantage demonstrates that for the world as a whole, free trade leads to a higher level of output and income than the state of autarky.

\subsection{Poverty}

Poverty is used to describe the condition whereby individuals or some groups of people lack or have limited access to the means of livelihood. In some instances, those who are described as being poor have a very shallow idea of what makes it congenital for living not to talk about not having such. Poverty is conceived with reference to families that have no sufficient cash, income to secure the minimum requirements of food, shelter and clothing (Atkinson et al., 1989; Khālid, 2003). According to Obomeghie and Ugbomhe (2021)., poverty is often conceptualized in three fundamental ways as a material condition when the income level of individuals is too limited to cover basic living conditions. Secondly, as the multidimensional condition where poverty can be context-specific, dynamic and social and political as well as economic. Thirdly, it refers to social relations concerning gender, labour and land which prevent individuals from improving their living conditions.

In Nigeria, poverty is such that education, which is generally seen to improve the employability of labour, increase income and ultimately reduce poverty cannot perform these cardinal roles and as such poverty is said to be everywhere. Poverty is seen among graduates of many years without any meaningful employment, it manifests amongst private-sector workers who are paid far below their marginal productivity. Those who have lost their farmlands done to herdsmen/farmers crises, as well as those whose lands have been hijacked by the Book Haram terrorists and are now in IDPs camps in many states of the federation. Poverty is seen among people in slumps and shanties of suburbs and satellite towns of major cities in Nigeria as well as villages whereby the people lack access to basic amenities and may not have the capital to scale up their farming and trading activities. These categories of people end up spending most of their earnings on food consumption and may not likely have the capacity to save for further investment.

Ajakaiye and Adeyeye(nd) perceived poverty as a situation that affects individual physical, moral and psychological state resulting from insufficient income to meeting basic needs. This means individual is unable to cater adequately for his basic foods, clothing and shelter. In addition, the individual lack ability to meet social and economic obligations given the lack of gainful employment, skills, assets and self-esteem, and his limited access to social and economic infrastructure such as education, health, potable water, and sanitation (Obomeghie \& Ugbomhe, 2021).

\subsection{Economic Development}

Sen (1999) considered economic development as the strengthening of autonomy and substantive freedom, which allows individuals to fully participate in economic life. It is also be regarded as a situation that enables individual agents to explore all the necessary opportunities to develop their capacities and actively participate in the nation's economic activities (M. Feldman, Hadjimichael, Lanahan, \& Kemeny, 2016). The challenge confronting Nigerian economic development is the lack of economic participation by the labour force. This further explains why economic growth is not the same as economic development as many periods of economic prosperity in Nigeria do not translate to stemming poverty, economic transformation, employment generation and sustainability. Economic development has to do with the removal of deprivation from poverty, hunger, illiteracy, illness, poor health and powerlessness, voicelessness, insecurity, humiliation and difficulties in accessing basic infrastructure (Narayan, Patel, Schafft, Rademacher, \& Koch-Schulte, 2000).

According to $\mathrm{V}$. Feldman and Kothari (2014) economic development is about placing the nation on a higher growth trajectory. It is concerned with structural transformation, knowledge development, transfer, and infrastructure improvement which can be brought about through efficient interactions between the public and private sectors. The free trade area implies that both tariff and non-tariff barriers inhibiting the optimal performance of countries especially the developing countries in the international market. According to Unctad (2014) exportations of agricultural produce from less developed countries is faced with an average tariff of 5 per cent and non-tariff trade restrictiveness of 27 percent. The non-tariff includes the sanitary and plytosamitory measures and technical standards which increasingly restrict export flows from the less developed countries. Free trade area brings about high degree of trade openness which permits international trade among partners' countries.

According to Bank (2018), trade is expected to impact the wellbeing of an individual nation's economy and reduction of poverty. Rapid and sustained growth allows the poor opportunities to increase their initial endowments by saving to accumulate capital, get the education to increase human capital and earn better rewards for supplying their resources to others. Nigerian cannot develop its resources to full potential without fully integrated into the regional and continental trade agreement to attain free trade area. Regional integration is inevitable for economic transformation and sustainable socio-economic development in Africa (lhua et al., 2018). For Africa to optimize its resource endowments and translate them into welfare gains for the teaming population, regional integration is inevitable (lhua et al., 2018). 
According to Bank (2018) trade liberalization leads to welfare gains in the form of consumer surpluses arising from the ability of consumers to access a greater variety of products in domestic markets and reduced importation. Nigeria imports the most important goods into the economy, consumer goods and producer goods alike. This implies that the existence of a common market between trading partners leads to the reduction of the cost of producing and price of consuming final goods which translates to welfare gains and poverty reduction.

Trade brings about specialization which is imperative to the development of every nation's economy including Nigeria. According to Finlayson et al. (2019)after trade liberalization, countries specialize in the production of goods in which they have a comparative advantage vis-à-vis their trade partners. This specialization is considered to have the propensity of raising output as the process allows better and more efficient use of productive resources in economies. The gains of free trade area are critical to economic development in Nigeria, but efforts should be made to create the atmosphere for both domestic and foreign private investment through diversification and capacity building to enhance innovation and competitiveness within the domestic economy. Reduction in trade barriers would not benefit all Africa countries on the equal population as welfare gain will be more accrued to the countries with the most open economies (Finlayson et al., 2019).

\subsection{Empirical Literature Review}

Free trade area has been observed to contribute significantly to the promotion of economic growth, poverty reduction and economic growth, as document ted by several empirical studies with mixed findings. Though, most of the studies by Mohler, Weder, and Wyss (2018) examined the relationship between international trade and unemployment in Switzerland. Their study made us of panel data covering 1991 to 2014 and employed linear probability model (OLS) and logit model, their findings revealed no positive relationship between import competition and employment of low-skilled individuals. In another study, Tanyi (2015), analysed the benefits and unexploited trade potentials of African regional markets. He utilized an augmented multi-linear gravity model regression analysis and discovered that there are projected gains to be generated from the establishment of a Pan-African continental free trade area.

Brassington et al. (2015) examined regional integration and intra-African trade barriers reductions using a simulation approach. Their findings revealed that tariff elimination on intra-African trade is promising but concluded that free trade agreement with selected African countries indicates that it is the second-best option. A similar conclusion was reached on the study undertaken by Hummels (2007) where they estimated the effect of removal of tariffs on intra-African trade among African countries using the CGE (computable general equilibrium) model. In their study, they established that the share of intra-Africa trade will increase from 10.2 per cent in 2011 to 15.5 per cent in 2022. Kabir (2017) established a negative inverse between trade liberalization and price incentives which theoretically is believed to stimulate domestic production. However, the authors remarked that in the long run, simulation of full trade liberalization would increase world real income by 0.33 per cent after ten years of implementation. They claimed that the middle-income countries will have a share of 0.5 per cent, and the least developed countries by 0.8 percent. Abrego, Amado, Gursoy, Nicholls, and Perez-Saiz (2019) estimated the welfare effects of African continental free trade areas for 45 countries. The authors utilized the multi-country and multi-sector general equilibrium model and discovered that partial and substantial reductions in non-tariff barriers will result in worthy gains from trade liberalization in Africa.

To estimate the effects of international trade on unemployment, Kim, Kundu, Viollet, and Guan (2011) utilized panel data from twenty (20) OECD countries and discovered that increase in trade brings about higher aggregate unemployment due to its interaction with rigid labour market institutions. However, the study of Kim also posited that trade may reduce unemployment if the labour market institutions are flexible thereby concluded that rigidities in the labour market act as an antithesis to employment creation through international trade. In another development, Fugazza and Miklósi (2014) analysed the policy issues and simulated discussions in the area of international trade and development. Their study used panel data covering the period of 1995 to 2009 from 97 countries to assess the relationship between openness to trade and unemployment. The authors discovered that the effect of international trade unemployment could either be positive or negative depending on the direction of the covariance of comparative advantage and sector level of labour market functions existing in the economy. The authors asserted that trade and unemployment could be positive if there is positive covariance or otherwise.

In the study of de Jong and de Steur (2016) the relationship between international trade regulation and job creation was investigated. The author utilized correlation analysis to determine the relationship between labour force participants and export plus import in gross domestic product data within the period 1990 to 2012 and submitted that trade policy does not have much impact on unemployment. He further remarked that there are differentials in the impact of the policy of trade from one country to another.

\section{METHODOLOGY}

\subsection{Theoretical Framework}

In studying the implications of regional integrations or free trade areas, theorists Hamanaka (2013) have found the computable general equilibrium (CGE) and gravity model to comprehend the effects of Trade Agreements. The CGE model focused on the study of the welfare effects of the trade agreement (whether free or partial trade restrictions) among countries. Rumpf et al. $\underline{(2010)}$ pointed out the significance of the CGE model in the determination of free trade implications which include among others, the consistency with the microeconomic theoretical framework, and production of quantitative results that enabled the policymakers to identify those that benefits and lose from free trade area/agreement. By so doing, the proponents of the CGE model documented the possibilities of studying welfare implications via compensating variations, factors returns (wages, rents, profits and interest), trade volumes whether aggregated or disaggregated, imports, exports, changes in trade balances, impact on 
dynamic variables (changes in capital flows, foreign direct investments, productivity spillovers, economies of scales/imperfect competition and so on.

However, the gravity model according to Rumpf et al. (2010) concerns with ex-post effects of trade flow. This means that the gravity model is suitable to assess the implications of trade flow in a situation where it (free trade area agreement) had not been in practice to guide the policymakers on decision making relating to free trade area agreement. Hamanaka (2013) has been considered as the pioneer of the gravity model where he compared the bilateral trade between two countries. It determines the import demands and made use of several explanatory variables like income of importing and exporting country, per capita income of the importing exporting country, distances between countries and other variables thought to be relevant by the Modeler (Plumer et al., 2010). Therefore, to measure the implications of the free trade area, this study found gravity theory as the appropriate theoretical framework. The stability of the gravity equation and its ability to explain bilateral trade flows led to the development of theories that could incorporate in the model for forecasting the effects of trade flows.

The econometric form of gravity model is represented as :

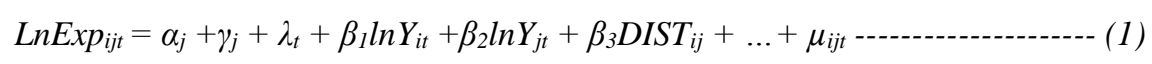

Where:

Exp $_{\mathrm{ijt}}$ is the volume of trade (exports) from country $i$ to country $j$ at time $t$

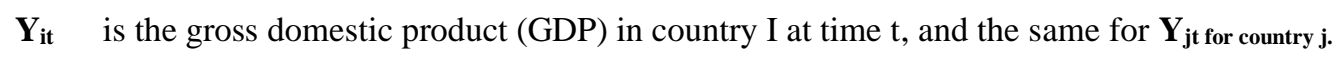

DIST $_{\mathbf{i j}}$ is the distance between the countries $\mathrm{i}$ and $\mathrm{j}$

$i=1, \ldots N, j=1 \ldots i-1, i+1, \ldots, N+1$

\subsection{Data}

The study employed time series data covering the period of 27 years (1991 to 2017). Data relating to per capita income (PCI), export contribution to gross domestic product (EXPGDP), gross domestic product (GDP), unemployment rate (UNR) and foreign direct investment (FDI) were sourced from the Central Bank of Nigeria statistical bulletin of 2018.

\subsection{Method}

To explore the implications of free trade area for poverty, descriptive (mean, standard deviation, skewness and kurtosis) and inferential approach (fully modified ordinary least square) (FMOLS) techniques were used to determine the implications of free trade area on the welfare and poverty level in an economy.

\subsection{Specifications of models}

To realize the objectives of the study, we modified the Tinbergen (1962) gravity model and empirical propositions to specify two models; welfare and poverty proxied by per capita and unemployment that were utilised to investigate the implications of the free trade area. The export contributions to the gross domestic product, foreign direct investment, and per capita income of individuals and unemployment rate were variables deemed incisive from empirical evidence to measure the degree of wellbeing derived from trades Sabina and Eldin (2018). Rumpf et al. (2010) included tariff rate and domestic investment as the determinants of real gross domestic per capita in their model to access the implications of trade activities on welfare. Kim et al. $\underline{(2011)}$ also modelled the effects of trade on unemployment among 20 organizations for economic co-operation and development (OECD) countries.

The implications of free trade area on poverty, per capita income (PCI) or the average income earned per person in a given country in a specified year becomes a very important index. The index allows the comparison of income derived from various sectors of the economy such as export and foreign direct investment as well as the wealth of different populations. The incorporation of these indexes in the study helps to ascertain the level of development and readiness of a country(s) like Nigeria in Africa to sign into free trade area agreement. However, differential in countries purchasing power parity, inflation, level of skewness in income distributions and non-monetary activities may undermine the significance of per capita income as an adequate measure of the implication of free trade area for poverty. In spite of the drawbacks, per capita income remains above other indexes for measuring the standard of living of populations in a given society.

In light of the framework, the functional and econometric relationships of the models are stated as thus:

Welfare $=\mathrm{f}($ Free trade area $)$

Where:

Welfare is proxied by Per capita income as the outcome variable.

The free trade area is represented by export contributions to gross domestic product (EXPGDP), foreign direct investment (FDI) and gross domestic product (GDP) as the explanatory variables. On this basis equation 2 is re-specified as thus:

Welfare $(P C I)=f(F D I, E X P G D P, G D P)$

Where: 
PCI is the per capita income which is used as a measurement of households welfare resulted from the participation in trade. Per capita income is deemed important a measure of welfare because the living standard or the wellbeing of the individual households can be determined (Hossain, Kamal, Halim, \& Zayed, 2019).

FDI is a foreign direct investment that measured the impact of growth per capita income is receiving so as to determine the policy implication of signing into free trade area agreement. Foreign direct investment (FDI) is found important in this study because is one of the economic activities that contribute to country trade balance and has implication on the welfare of the individual households through the improvement in incomes (Hossain et al., 2019).

EXPGD is the export contribution to gross domestic product. It is used to measure the impact and the contributions of trade activities to the growth per capita of individual households' welfare. This is to determine the implications of free trade area policy as entrenched in the African continental free trade area (ACFTA) which the Nigerian government signed into.

GDP is the gross domestic product that measures the overall performance of an economy. It is employed in this study to determine the indirect impact of trade on the welfare of the households through per capita income. This is in line with (Paul, 2010) study that dwelt on the relationship between gross domestic product and welfare in Denmark. The variables of this study were selected to measure the degree of households' welfare implications of trade under existing trade restrictions policy to determine what the country stands to benefit under non-restrictive trade policies among Africa countries.

Equation 1, implies that per capita income (PCI) is a function of export contributions to gross domestic product (EXPGDP), foreign direct investment (FDI), and gross domestic product (GDP) which is in line with Sabina \& Eldin( 2018); Abrego, Amado, Gursoy, Nicholls, \& Perez-Saiz (2019).

To permit empirical analysis, equation 2 is formulated econometrically as thus:

Welfare $=\alpha_{0}+\alpha_{1} E X P G D P+\alpha_{2} F D I+\alpha_{3} G D P+e$

Where,

e is the error term assumed to be normally distributed with zero and constant variance. It is employed to capture the effect of implications of free trade area for poverty that could not be captured by the parameters of the explanatory variables in the model.

A priori, $\alpha_{1}, \alpha_{2}, \alpha_{3}$, are to be greater than zero. To determine the poverty implications of the free trade area, the following equation is specified thus:

Poverty $=\mathrm{f}($ free trade area $)$

This implies that poverty is a function of the free trade area. For estimation purposes, poverty is proxied by unemployment as the dependent variable and trade area to be represented by foreign direct investment(FDI) and export contributions to gross domestic product(EXPGDP). On this basis equation 5 is re-specified as:

$\operatorname{Poverty}(U N R)=f(F D I+E X P G D P)$

Where:

Poverty is the outcome variable. It measures the poverty implications of the free trade area and is proxied by the unemployment rate. This is in line with (Kim,2011; Mohler, Weder, and Wyss, 2018) who determined the poverty implications of free trade areas using unemployment as their outcome variable.

PCI is Per capita income which in the gravity model of Tinbergen (1962) is used as the gross domestic product but modified here as per capita income.

EXPGDP is the contribution of export proceeds to gross domestic product.

FDI is a foreign direct investment as described in the preceding paragraph were the explanatory variables which are used as proxies to measure the implications of free trade area on poverty that is proxied by unemployment under existing restrictive trade policies.

To give econometric content to equation 6 , it was reformulated as thus:

$\operatorname{Poverty}(U N R)=\beta 0+\beta 1 F D I+\beta 2 E X G D P+\mu$ (7)

Where,

$\mu$ is the error term, assumed to be normally distributed with zero mean constant variance. Other explanatory variables remain as defined under equation 6.

The parameters in model $7 \mathrm{viz} ; \beta 1$, and $\beta 2$ are expected to have an inverse relationship with the dependent variable (unemployment rate (UNR) proxied for poverty to indicate implications of free trade area on employment.

This study adopts a step-by-step approach estimation in obtaining final estimates of the variables of the study.

Step 1: This involves a preliminary investigation of the stochastic properties of the variables especially the normality assumptions. This was done using the normality tests( Skewness, Kurtosis and jarque-Bera).

Step 2: This involved the determination of stationarity of the variables using the Augmented Dickey-Fuller(ADF) test of unit root and complemented by the Phillip-perrron test. This was to ensure the data are stationary before obtaining estimates that are 
not spurious. The series was tested for stationarity at level $\mathrm{I}(0)$, which is integrated to order 0 . It was discovered that stationarity was not achieved at a level among most of the series. The data were subjected to the first difference I(I) when a level of stationarity was established.

Step 3. This stage involves the estimation of the coefficients of the variables having established stationarity at the first difference for all the variables utilizing the fully modified ordinary least square(FMOLS) method.

\section{RESULTS AND DISCUSSION}

\subsection{Presentation of Results}

TABLE 1

Descriptive Statistics

\begin{tabular}{|c|c|c|c|c|c|}
\hline & PCI & EXPGDP & FDI & GDP & UNR \\
\hline Mean & 1377.296 & 22.44852 & 3.49296 & 203.2859 & 4.07370 \\
\hline Median & 1008.000 & 23.02000 & 2.01000 & 104.9100 & 3.95000 \\
\hline Maximum & 3223.000 & 36.02000 & 8.84000 & 568.5000. & 6.24000 \\
\hline Minimum & 270.000 & 9.22000 & 0.09000 & 27.7500 & 3.42000 \\
\hline Std. Dev. & 970.322 & 6.45966 & 2.65127 & 178.2900 & 0.69129 \\
\hline Skewness & 0.4381 & -0.11606 & 0.65658 & 0.69094 & 2.164247 \\
\hline Kurtosis & 1.6950 & 2.71658 & 2.16053 & 1.98180 & 6.82553 \\
\hline Jarque-Bera & 2.77957 & 0.150986 & 2.73275 & 3.31459 & 37.54187 \\
\hline Probability & 0.249128 & 0.92729 & 0.25509 & 0.190653 & 0.00000 \\
\hline
\end{tabular}

Source: Author's computations.

Table 1 is the summary (descriptive) statistics which shows that the means and medians values of the respective variables are almost the same, demonstrating even distribution except for the PCI and GDP series. The deviation from the means depicted by the standard deviation indicates that the variable, unemployment rate (UNR) had the lowest standard deviation, followed by foreign direct investment(FDI) and export contributions to gross domestic product(EXPGDP). The income per capita (PCI) had the highest standard deviation which was followed by gross domestic product (GDP). The values of the standard deviation of the respective variables are less than their respective means values, indicating non-chances of volatility in the series. The skewness results revealed that EXPGDP is negatively skewed with left long tail while PCI, UNR, and GDP are positively skewed with right tails. The results of kurtosis of PCI (1.7), EXPGDP(2.7), FDI(2.2), GDP(2.0) were approximately less than kurtosis 3.0(standard normal distribution) revealed that the variables have a platykurtic distribution which is flatter than normal distribution while the value of 6.8 indicates that URN is leptokurtic(peaked than normal distribution). The large values of the Jarque-Bera test for normality indicate that errors are not normally distributed among the variables except the variable EXPGDP with a J-B value close to zero(0.2).

To determine whether or not the data were stationary, the Augmented Dickey-Fuller (ADF), Phillip-Perron(PP) and Kwiatkowski-Phillips-Schmidt-Shin (KPSS) unit root test were employed. The results of the unit root test among the variables in the study are presented in Tables 2 and 3.

TABLE 2

Summary of ADF Unit Root Test Results

\begin{tabular}{llllll}
\hline Variable & Level & Prob.Value & First difference & Prob. Value & Order of Integration \\
& & & & & \\
\hline PCI & -0.80334 & 0.4297 & $-3.229881^{*}$ & 0.003 & $\mathrm{I}(1)$ \\
\hline EXPGDP & -2.960235 & 0.006 & $-6.549474^{*}$ & 0.001 & $\mathrm{I}(1)$ \\
\hline FDI & -1.499815 & 0.1467 & $-5.970008^{*}$ & 0.001 & $\mathrm{I}(1)$ \\
\hline GDP & -0.304799 & 0.7631 & $-2.636033^{* *}$ & 0.014 & $\mathrm{I}(1)$ \\
\hline UNR & -3.215202 & 0.0040 & $-3.902205^{*}$ & 0.001 & $\mathrm{I}(1)$ \\
\hline Asymptotic & Critical Values & & & & \\
\hline $\mathbf{1 \%}$ & -3.711457 & & & & \\
$\mathbf{5 \%}$ & -2.981038 & & -3.724070 & & \\
$\mathbf{1 0 \%}$ & -2.629906 & -2.986225 & &
\end{tabular}

\footnotetext{
* implies significant at $1 \%$ level and ** significant at $5 \%$ level
}

Table 2 shows the Augmented Dickey-Fuller test for stationarity(unit root) of the variables series. The results revealed that at level, two(2) variables which are an export contribution to gross domestic product(EXPGDP) and unemployment rate (UNR) attained stationarity. They were significant at $1 \%$ level as depicted by their respective P-value of 0.006 and 0.004 , thereby leading to the rejection of the null hypothesis of non-stationarity of the two variables. The result of the first difference indicated that all the variables attained stationarity and were statistically significant at $1 \%$ level except GDP that was statistically significant at $5 \%$ level.

TABLE 3

Summary of Phillip-Perron(PP) Unit Root Test Results

\begin{tabular}{|c|c|c|c|c|}
\hline Variable & $\begin{array}{l}\text { Phillip-Perron } \\
\text { Statistic value }\end{array}$ & $\begin{array}{l}\text { PP Test Critical } \\
\text { value }(5 \%)\end{array}$ & Probability & Order of Integration \\
\hline
\end{tabular}




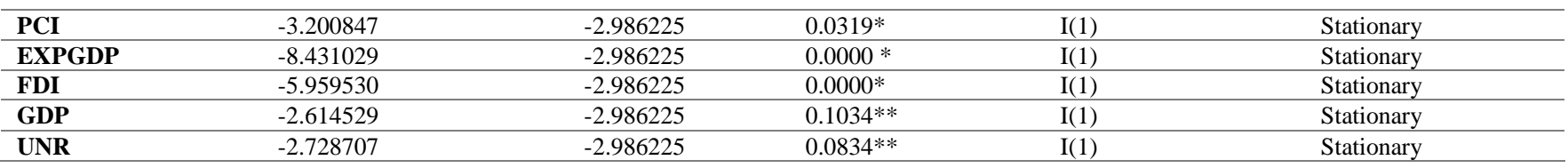

* implies significant at 5\% level and ** significant at $10 \%$ level

Source: Author's computations (2020) using Eviews7.

Table 3 shows the Phillip-perron unit root test results. The results indicated that all the variables except EXPGDP are nonstationary at levels because their calculated Phillip-perron(PP) values are less than their critical values at the 5\% level. To further complement the test of stationarity of the series used in the study, the Kwiatkowski-Phillips-Schmidt-Shin (KPSS) test statistic was equally utilized.

TABLE 4

Summary of Kwiatkowski-Phillips-Schmidt-Shin (KPSS) Unit Root Test Results

\begin{tabular}{|c|c|c|c|c|}
\hline Variable & $\begin{array}{l}\text { KPSS(LM) } \\
\text { Statistic value }\end{array}$ & $\begin{array}{l}\text { KPSS Test Critical } \\
\text { value }(1 \%)\end{array}$ & Order of Integration & Remarks \\
\hline $\log (P C I)$ & 0.185059 & $0.739000 *$ & $\mathrm{I}(1)$ & Stationary \\
\hline $\log ($ EXPGDP) & 0.190039 & $0.739000^{*}$ & $\mathrm{I}(1)$ & Stationary \\
\hline $\log ($ FDI $)$ & 0.500000 & $0.739000^{*}$ & $\mathrm{I}(1)$ & Stationary \\
\hline $\log ($ GDP $)$ & 0.175257 & $0.739000 *$ & $\mathrm{I}(1)$ & Stationary \\
\hline $\log ($ UNR $)$ & 0.242257 & $0.739000^{*}$ & $\mathrm{I}(1)$ & Stationary \\
\hline
\end{tabular}

Source: Author's computations (2020) using Eviews7.

The result of the Kwiatkowski-Phillips-Schmidt-Shin (KPSS) test statistic of unit root indicated that the series is stationary after the first difference and statistically significant at 1 percent level. The KPSS(L-M) statistics values of all the series are less than the KPSS test critical values, therefore, leading to the acceptance of the null hypothesis of stationarity of the series. The remarkable difference between KPSS on one hand, ADF and PP test statistics on the other is that the null hypothesis of Kwiatkowski-Phillips-Schmidt-Shin (KPSS) is stated as "stationary" and the log the variables must be taken. On the other hand, the Augmented Dickey-Fuller (ADF) and Phillip-Perron (PP) null hypothesis is stated in the negative form as "non-stationary" and the variables need not be logged before the application of the test.

TABLE 5

Welfare equation estimate proxied by per capita income (PCI)

\begin{tabular}{|c|c|c|c|c|}
\hline \multicolumn{5}{|c|}{ Dependent Variable: PCI } \\
\hline \multicolumn{5}{|c|}{ Method: Fully Modified Least Squares (FMOLS) } \\
\hline \multicolumn{5}{|c|}{ Date: 11/16/20 Time: 00:19 } \\
\hline \multicolumn{5}{|c|}{ Sample (adjusted): 19922017} \\
\hline \multicolumn{5}{|c|}{ Included observations: 26 after adjustments } \\
\hline \multicolumn{5}{|c|}{ Cointegrating equation deterministic: $\mathrm{C}$} \\
\hline \multicolumn{5}{|c|}{ Long-run covariance estimate (Bartlett kernel, Newey-West fixed bandwidth $=3.0000$ ) } \\
\hline Variable & Coefficient & Std. Error & t-Statistic & Prob. \\
\hline FDI & 75.20961 & 18.27667 & 4.115061 & 0.0005 \\
\hline EXPGDP & 20.40409 & 5.929150 & 3.441318 & 0.0023 \\
\hline GDP & 4.654515 & 0.290404 & 16.02771 & 0.0000 \\
\hline $\mathrm{C}$ & -322.0895 & 147.7193 & -2.180416 & 0.0402 \\
\hline R-squared & 0.956553 & \multicolumn{2}{|c|}{ Mean dependent var } & 1410.923 \\
\hline Adjusted R-squared & 0.950628 & \multicolumn{2}{|c|}{ S.D. dependent var } & 973.3620 \\
\hline S.E. of regression & 216.2787 & \multicolumn{2}{|c|}{ Sum squared resid } & 1029082. \\
\hline Durbin-Watson stat & 1.744199 & \multicolumn{2}{|c|}{ Long-run variance } & 26018.87 \\
\hline
\end{tabular}

Source: Authors' computation using Eviews 7.

\section{DISCUSSION OF RESULTS}

From the estimated regression, it was observed that the coefficient of the explanatory variables: Foreign direct investment(FDI) export contribution to gross domestic product (EXPGDP) and gross domestic product(GDP) impacted on the welfare proxied by per capita income as implications of free trade area positively. This showed that a unit change in the FDI on the average while holding other variables constant brings about 75.21 units or a 7,520\% increase in the welfare of individual households. In the same vein, a unit change in the export contributions to gross domestic products leads to about 20.40 units or a $2,040 \%$ rise in welfare proxied by per capita income of individual households. Again, it was observed from the estimate that a unit change in the gross domestic product (GDP) on the average while holding other variables constant, leads to about 4.65 or $465 \%$ increase in the welfare of the individual households. This implies positive contributions of free trade activities to promoting the wellbeing of the households. According to the estimates, the positive effects of the variables: FDI, EXPGDP and GDP were statistically significant given their t-statistics of 4.12 with a p-value of $0.001(1 \%) ; 3.44$ with a p-value of $0.001(1 \%)$ and 16.03 with a pvalue of $0.001(1 \%)$ level respectively. These findings are contrary to that of Balogun and Dauda (2012) who established a negative inverse between trade liberalization and price incentives which theoretically is believed to stimulate domestic production. However, similar to this study finding is the work of Jensen and Solheim (2020) and (Sabina \& Eldin, 2018) that was undertaken among selected African countries which indicates that regional integration and intra-African trade barriers 
reductions are the second-best options for promising wellbeing in the region. Also in line with the findings of the study is Abrego, Amado, Gursoy, Nicholls, and Perez-Saiz (2019)who documented international trade as welfare promoting policy.

The combined effect of the explanatory variables on the welfare proxied as per capita income (PCI) measured by the $\mathrm{R}^{2}=0.956$ indicates that approximately 96 percent of the total variation in the welfare proxied by per capita income (PCI) was explained by the variables in the model. This leaves about $4 \%$ variations in PCI unexplained within the model which is, therefore, attributable to an extraneous factor outside the model. This indicates that the model is well-fitted. The Durbin Watson statistics (1.7) indicates the non-presence of serial autocorrelation.

\section{TABLE 6}

poverty equation estimate proxied by the unemployment rate

\section{Dependent Variable: UNR}

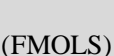

\begin{tabular}{|c|c|c|c|c|}
\hline Variable & Coefficient & Std. Error & t-Statistic & Prob. \\
\hline FDI & -0.213947 & 0.040364 & -5.300496 & 0.0000 \\
\hline EXPGDP & -0.048861 & 0.012090 & -4.041379 & 0.0005 \\
\hline C & 4.804396 & 0.336055 & 14.29646 & 0.0000 \\
\hline @TREND & 0.085740 & 0.014465 & 5.927529 & 0.0000 \\
\hline R-squared & 0.729263 & \multicolumn{2}{|c|}{ Mean dependent var } & 4.093462 \\
\hline Adjusted R-squared & 0.692345 & \multirow{2}{*}{\multicolumn{2}{|c|}{$\begin{array}{l}\text { S.D. dependent var } \\
\text { Sum squared resid }\end{array}$}} & 0.697171 \\
\hline S.E. of regression & 0.386698 & & & 3.289773 \\
\hline Durbin-Watson stat & 1.712764 & \multicolumn{2}{|c|}{ Long-run variance } & 0.126686 \\
\hline
\end{tabular}

Source: Authors' computation using Eviews 7.

The poverty model proxied by unemployment estimated the relationship between the unemployment rate (UNR) and the explanatory variables: export contribution to gross domestic product ( EXPGDP) and Foreign Direct Investment (FDI). The result of the estimates indicates that the two variables viz Export contributions to gross domestic product (EXPGDP) and foreign direct investment (FDI) demonstrated a negative relationship with poverty represented by the unemployment rate. The study estimates of the coefficient indicate that a unit change in the FDI while holding other variables constant leads to a reduction in the unemployment rate by -0.0488 or $(4.9 \%)$. It was documented to be statistically significant at $1 \%$ level as demonstrated by the t-statistics (4.04) in absolute terms and p-value (0.001). In the same token, a unit change in the export contribution to gross domestic product (EXGDP) while holding other variables constant brings about $-0.2139(21.39 \%)$ reductions in the unemployment rate. It was discovered to be statistically significant at $1 \%$ level given the t-statistics value of 5.30 with a p-value of 0.001 . The employment promoting variables documented by this study is in line with the submission of Kim (2011) who asserted that international trade policy promotes employment.

To determine the explanatory power of the model, the coefficient of determination $\left(\mathrm{R}^{2}\right)$ revealed 0.729 which indicates that approximately about $73 \%$ of the variation in the unemployment rate was explained by the variables in the model while about $0.27(27 \%)$ was unexplained by the model which was attributed to the extraneous variables outside the model. The adjusted $\mathrm{R}^{2}$ stood at $0.69(69 \%)$ which is still above $50 \%$ of households of significant level.

The Durbin-Watson statistics $=1.71$ which shows that there is the absence of serial correlation or autocorrelation among the variables. From the result, it can be deduced that export contribution and foreign direct investments (FDI) have the potential in reducing the rate of unemployment thereby reducing the poverty and promoting the wellbeing of the masses. To this end, it can be established that if export and foreign direct investment is fully harnessed through free trade activities among the nation, unemployment will be further reduced to an acceptable rate.

\section{CONCLUSION}

The researchers looked into the effects of free trade zones on poverty, household welfare, and economic progress. The study used time series data from 1991 to 2017 to estimate welfare, which was proxied by income per capita, and poverty, which was proxied by unemployment models. To fulfill the study's goal, the coefficients of the determinants, which are export contributions to gross domestic product (EXPGDP), foreign direct investment (FDI), and gross domestic product (GDP), were estimated using a completely modified ordinary least squares regression technique (GDP).

The study documented that there exist positive relationships between the foreign direct investment (FDI), contribution of export to gross domestic product, and gross domestic product which were employed to estimate the free trade area contributed implications on welfare captured by per capita income of individual households. This implies that foreign direct investment promotes welfare in a country whose free trade area policy enable investors from other countries to participate in business or investment activities. Again, the study concluded revealed that the export contributions to gross domestic product (EXPGDP) have a positive significant implication on the welfare of the individual households. This implies that the more the volume of export contributions the more positive welfare effects on the masses. Besides, the results showed that gross domestic product (GDP) promotes the welfare of individual households. It was also ascertained from the study that foreign direct investment (FDI) and export contributions to gross domestic product (EXPGDP) led to the decline in unemployment Based on the findings, the study recommends that: to further promote households' welfare and reduce poverty, actionable policies such as removal of restriction on the investors' permits, business registration requirements and other necessary policies that may provide enabling 
environment to make a business thrive as well as promotes foreign direct investment(FDI) should be emphasised. Again, policies that promote export, such as reduction in tariff, simplifying regulations, increasing the availability of credit to exporters, creations of duty drawbacks and improving cooperation among economic actors should be emphasised to reap the full benefits of free trade areas like welfare improvement and poverty reduction. Besides, to promote growth to further positively enhance the welfare of the households and reduce poverty, policies that accelerate the country's output such as structural changes and infrastructural development should be stressed.

However, due to its noble nature, this study was unable to achieve its goal without experiencing some difficulties. Obtaining the necessary data and variables to capture free trade zones and their effects on household well-being, as well as anticipating future free trade zone effects, are among them. Though, to a large extent, this study successfully navigated this snag by employing appropriate variables and data as proxies to achieve its goal. On this premise, the study suggests that further research be done in this field, particularly forecasting and predicting studies on the effects of free trade zones.

\section{REFERENCES}

Abrego, M. L., Amado, M. A., Gursoy, T., Nicholls, G. P., \& Perez-Saiz, H. (2019). The African Continental Free Trade Agreement: welfare gains estimates from a general equilibrium model: International Monetary Fund.

Abubakar, I., \& Obansa, S. (2020). An Estimate of Average Cost of Hypertension and its catastrophic effect on the people living with hypertension: Patients' perception from two Hospitals in Abuja, Nigeria. International Journal of Social Sciences and Economic Review, 2(2), 10-19.

Ahmad, I. (2021). Emotional Regulation as a Remedy for Teacher Burnout in Special Schools: Evaluating School Climate, Teacher's Work-Life Balance and Children Behaviour. Frontiers in Psychology, 12, 2460.

Atkinson, R., Baulch, D., Cox, R., Hampson Jr, R. F., Kerr, J., \& Troe, J. (1989). Evaluated kinetic and photochemical data for atmospheric chemistry: supplement III. IUPAC subcommittee on gas kinetic data evaluation for atmospheric chemistry. Journal of Physical and Chemical Reference Data, 18(2), 881-1097.

Balogun, E. D., \& Dauda, R. (2012). Poverty and Employment Impact of Trade Liberalization in Nigeria: Empirical Evidence and Policy Implications.

Bank, W. (2018). Poverty and shared prosperity 2018: Piecing together the poverty puzzle. In: The World Bank.

Brassington, G., Martin, M., Tolman, H., Akella, S., Balmeseda, M., Chambers, C., . . . Jansen, P. (2015). Progress and challenges in short-to medium-range coupled prediction. Journal of Operational Oceanography, 8(sup2), s239-s258.

de Jong, M. F., \& de Steur, L. (2016). Strong winter cooling over the Irminger Sea in winter 2014-2015, exceptional deep convection, and the emergence of anomalously low SST. Geophysical Research Letters, 43(13), 7106-7113.

Feldman, M., Hadjimichael, T., Lanahan, L., \& Kemeny, T. (2016). The logic of economic development: a definition and model for investment. Environment and Planning C: Government and Policy, 34(1), 5-21.

Feldman, V., \& Kothari, P. (2014). Learning coverage functions and private release of marginals. Paper presented at the Conference on Learning Theory.

Finlayson, T., Cha, S., Xia, M., Trujillo, L., Denson, D., Prejean, J., . . Al-Tayyib, A. (2019). Changes in HIV preexposure prophylaxis awareness and use among men who have sex with men-20 urban areas, 2014 and 2017. Morbidity and Mortality Weekly Report, 68(27), 597.

Fugazza, C., \& Miklósi, Á. (2014). Deferred imitation and declarative memory in domestic dogs. Animal Cognition, 17(2), 237247.

Gap, G. G. (2017). World economic forum. Cologny/Geneva.

Grossman, G. M., \& Krueger, A. B. (1995). Economic growth and the environment. The quarterly journal of economics, 110(2), 353-377.

Hamanaka, S. (2013). A note on detecting biases in assessing the use of FTAs. Journal of Asian Economics, 29, $24-32$.

Hossain, M. S., Kamal, M. S., Halim, M. R., \& Zayed, N. M. (2019). Inward Foreign Direct Investment and Welfare Nexus: the Impact of Foreign Direct Investment on Welfare in Developing Countries. International Journal of Economics and Financial Issues, 9(4), 228-240.

Hummels, D. (2007). Transportation costs and international trade in the second era of globalization. Journal of Economic perspectives, 21(3), 131-154.

Ihua, B., Ike-Muonso, M., Taiwo, O., \& Mba-Kalu, S. (2018). An Independent Study On the Potential Benefits of The African Continental Free Trade Area (AFCFTA) On Nigeria. Nigerian Office for Trade Negotiations. https://www. tralac. org/documents/resources/by-country/nigeria/2029-an-independent-study-on-the-potential-benefits-of-the-afcfta-onnigeria-study-report-may-2018/file. html, accessed, 24, 2019.

Irwin, D. A. (2019). Does trade reform promote economic growth? A review of recent evidence.

Jensen, M. T., \& Solheim, O. J. (2020). Exploring associations between supervisory support, teacher burnout and classroom emotional climate: the moderating role of pupil teacher ratio. Educational Psychology, 40(3), 367-388. doi:10.1080/01443410.2019.1673881

Kabir, M. A. (2017). Continuance intention to use electronic collection system in Nigerian federal hospitals. Universiti Utara Malaysia,

Khālid, M. (2003). War and peace in Sudan: a tale of two countries: Routledge.

Kim, J., Kundu, M., Viollet, B., \& Guan, K.-L. (2011). AMPK and mTOR regulate autophagy through direct phosphorylation of Ulk1. Nature cell biology, 13(2), 132-141.

Krugman, P. (1993). First nature, second nature, and metropolitan location. Journal of regional science, 33(2), $129-144$.

Ma, J., \& Lu, Y. (2011). Free trade or protection: a literature review on trade barriers. Research in World Economy, 2(1), 6977. 
Mevel, S., \& Karingi, S. (2012). Deepening regional integration in Africa: a computable general equilibrium assessment of the establishment of a continental free trade area followed by a continental customs union. Paper presented at the 7 th African Economic Conference, Kigali, Rwanda.

Mohler, L., Weder, R., \& Wyss, S. (2018). International trade and unemployment: towards an investigation of the Swiss case. Swiss journal of economics and statistics, 154(1), 1-12.

Moroney, J. R., \& Walker, J. M. (1966). A regional test of the Heckscher-Ohlin hypothesis. Journal of Political Economy, 74(6), 573-586.

Narayan, D., Patel, R., Schafft, K., Rademacher, A., \& Koch-Schulte, S. (2000). Voices of the poor: Can anyone hear us? Voices from 47 countries. Washington, DC: World Bank, http://siteresources. worldbank. org/INTPOVERTY/Resources/335642-1124115102975/1555199-1124115187705/voll. pdf (accessed August 30, 2015).

Obomeghie, M., \& Ugbomhe, U. O. (2021). Globalization and Its Brunt on Nigeria Global Economic Competitiveness: The Need for Holistic and Dynamic Strategies. International Journal of Social Sciences and Economic Review, 3(1), 1-06.

Omoke, P. C., \& Busari, D. T. (2008). Private investment behaviour and trade policy practice in Nigeria: AERC.

Puzenat, E., Bronsard, V., Prey, S., Gourraud, P. A., Aractingi, S., Bagot, M., . . Le Maitre, M. (2010). What are the best outcome measures for assessing plaque psoriasis severity? A systematic review of the literature. Journal of the European Academy of Dermatology and Venereology, 24, 10-16.

Ricardo, D. (1956). Principles of Political Economy and Taxation, repr. P. Sraffa (ed.) The Works and Correspondence of David Ricardo, Vol. 1. In: Cambridge, Cambridge University Press for the Royal Economic Society.

Rumpf, T., Mahlein, A.-K., Steiner, U., Oerke, E.-C., Dehne, H.-W., \& Plümer, L. (2010). Early detection and classification of plant diseases with support vector machines based on hyperspectral reflectance. Computers and electronics in agriculture, 74(1), 91-99.

Sabina, S., \& Eldin, M. (2018). Do Environmental Taxes Pay Off? The Impact of Energy and Transport Taxes on CO2 Emissions in Transition Economies. South East European Journal of Economics and Business, 13(2), 126-143.

Sen, A. (1999). Commodities and capabilities. OUP Catalogue.

Tinbergen, J. (1962). Shaping the world economy; suggestions for an international economic policy.

Unctad, W. (2014). United nations conference on trade and development. Review of Maritime Transport. 